\title{
KEHIDUPAN BERAGAMA MASYARAKAT TATOR (Studi Kasus di Kelurahan Tikala Kec. Rantepao Kab. Tana Toraja)
}

\section{PENDAHULUAN}

Sasaran pembangunan jangka panjang yang hendak dicapai oleh bangsa Indonesia sebagaimana yang diamanatkan oleh Pembukaan UUD 1945 adalah tercapainya masyarakat adil dan makmur, sejahtera lahir dan batin. Usaha tersebut telah dilaksanakan secara bertahap melalui Pembangunan Jangka Panjang I (PJP I ), kemudian dilanjutkan pada tahap PJP II. Tahap itu merupakan batu pijakan yang sangat penting untuk tahap tinggal landas pada pelita V I, yang digambarkan sebagai proses pencapaian kehidupan bangsa yang lebih baik, namun penuh gejolak perubahan karena desakan pertumbuhan ekonomi, perkembangan teknologi, persaingan interanisional dan perubahan lingkungan hidup.
\end{abstract}

Ahmad Rahman
Untuk mencapai tujuan pembangunan nasional, pada dasarnya pembangunan sektor agama selalu ditetapkna untuk menumbuhkan regiositas masyarakat yang sekaligus juga berfungsi sebagai penangkal dampak negatif pembangunan. Oleh karena itu, pembangunan sektor agama lebih diarahkan untuk mencapai tiga kondisi ideal, yaitu : kader iman dan ketakwaan yang tinggi; wawasan keberagamaan yang luas dan matang; dan kerukunan kehidupan keberagamaan yang mantap dan dinamis untuk menyukseskan pembangunan.

Dalam rangka mencapai pemahaman tentang bagaimana corak kehidupan keberagamaan masyarakat, Badan Litbang Agama telah melakukan serangkaian penelitian tentang ketakwaan terhadap Tuhan Yang Maha Esa dalam berbagai sisteim sosial budaya masyarakat Indonesia. Dari hasil penelitian tersebut, diperoleh temuan yang memperkuat kenyataan selama ini banhwa masyarakat Indonesia memandang Tuhan Yang Maha Kuasa adalah bagian yang tidak terpisahkan dari kebudayaannya. tuhan adalah sumber acuan dan orientasi tertinggi dan utama dalam kehidupan manusia. Atau secara sederhana dapat dikatakan bahwa agama merupakan submer ethos dan pandangan hidup bangsa Indonesia.

Departemen Agama sesuai dengan tugas pokok dan fungsinya, yaitu memberikan pelayanan dan bimbingan kehidupan agama kepada masyarakat, dan ditutut memperhatikan perubahan yang ada. Apakah pelayanan dan bimbingan itu sudah berjalan dengan baik, dan apakah kebijaksanaan yang diambil sejalan dengan aspirasi masyarakat. Untuk menjawab pertanyaan itu, diperlukan penelitian. 
Permasalahan penelitian ini dirumuskan dalam empat pertanyaan pokok, yaitu : 1) bagaimana bentuk dan fungsi institusi agama yang ada, 2) bagaimana pola-pola akulturasi dan inkulturasi agama melalui berbagai pendidikan, 3) bentuk-bentuk penerangan agama yang bagaimana dibutuhkan masyarakat, dan 4) literaturliteratur keagamaan apa yang banyak dibaca dan dibutuhkan masyarakat.

Penelitian ini dilakukan di Kelurahan Tikala Kecamatan Rantepao Kabupaten Tana Toraja. Pengumpulan data dilakukan dengan memaki teknik wawancara mendalam dengan tokohtokoh adat, tokoh-tokoh agama serta beberapa pejabat formal. Selain itu, juga pengamatan intensif terhadap kehidupan sosial keagamaan dan ditambah dengan studi dokumen dan kepustakaan. Data yang terkumpul diolah dan diahalisis secara kualitatif dengan deskriktif.

\section{GAMBARAN UMUM KELURAHAN TIKALA}

Kelurahan Tikala adalah salah satu kelurahan di Kecamatan Rantepao. Jarak pusat pemerintahan Tikala dengan pusat pemerintahan Kecamatan Rantepao tiga setengah kilometer, jurusan Sa'dan melalui Jalan Suluara. Kalambe adalah lingkungan pertama yang dimasuki, dan terdapat tulisan dalam bahasa Toraja pada pintu gerbang, yaitu "Misa kada diputuo pantan kada dipomate" (Bersatu kita teguh bercerai kita runtuh). Sekitar 500 meter daeri pintu gerbang, di bukit $\mathrm{s}$ ebelah kanan berdiri sebuah gereja yang dinamai Gereja Protestan Tana Toraja. Gereja itu adalah yang per- tama di Tana Toraja. Sekitar 500 meter dari gereja itu, terdapat Sekolah Pendidikan Guru Kristen, terletak di pinggir jalan raya menuju Lingkungan Buntu Barana, di sekolah itu dahulu sebagai pusat pendidikan zending di Sulawesi Selatan.

Kampung Barana dan Kalamber tercatat sebagai pusat penyebaranlnjil. Pada tahun 1914, sudah ada sekolah zending di Kalamber. Sekolah itu didirikan oleh pendeta Belanda yang bernama Antonis Aris van de Loosdrecht. Sekolah itu dijadikan taempat kebaktian sebelum didirikan gereja di Kalambe. Pada tanggal 11 Juli 1917, telah dibaptis sembilan pemuda Kalambe, dan merupakan pembaptisan kedua setelah dibaptis lima orang di Rantepao pada tanggal 23 Mei 1915. Sekolah zending yang didirikan oleh Loosdrecht diasuh oleh guru-guru dari Manafo dan Ambon (Sarira, 1975 : 35). Sekolah itu telah mengeluarkan murid-murid yang kemudian memegang peranan penting dibindang pendidikan dan pemerintahan. Sekolah zending itu sekarang telah menjadi SMPN Kalamber, terletak di pinggir jalan menuju kampung Pauluasu.

Pasar sebagai pusat perekonomian masyarakat Rantepao pada mulanya berada di Kelurahan Tikala, yaitu di Karangan, kemudian pindah di Kalambe, selanjutnya pindah ke Malango (sekarang masuk wilayah Kelurahan Rantepao), kemudian pindah ke Rantepao (sekarang terminal), dan terakhir pindah ke Bolu (Kelurahan Tallunglipu) setelah terjadi kebakaran pasa Rantepao pada tahun 1987. SEjak dahulu, mata pasar sekali dalam enam hari, sudah ada usaha 
untuk merubah mata pasar, tetapi tidak pernah berhasil, karena masyarakat tidak datang pada hari yang ditetapkan.

Kelurahan Tikala telah diprogramkan menjadi daerah wisata. Untuk mendukung program itu, telah didirikan sebuah hotel yang diberi nama Wisata Tikala. Hotel itu dibangun oleh seorang pengusaha Cina dari Rantepao yang kawin dengan orang Tikala. Ada beberapa tempat wisata yang ditawarkan lewat informasi di pasang di pinggir jalan menuju lokasi wisata, seperti Buntu Barana, Kande Api, Taroallo, Sesean Ula dan Selo. Objek wisata antara lain kuburan, kubu-kubu pertahanan, dan perkampungan orang Toraja. Informasi itu ditulis dalam bahasa Indonesia, kemudian diterjemahkan dalam bahasa Inggeris. Objek wisata tersebut belum banyak pengunjunghya, karena belum dikelola dengan baik. Diperoleh informasi bahwa belum ada anggaran untuk memperbaiki objek wisata tersebut, sehingga sampai sekarang belum dapat memberikan pajak pendapatan kelurahan.

Tidak diperoleh keterarigan yang jelas asal kata tikala, tetapi diperoleh informasi bahwa kata tikala berasal dari kata patikala, yaitu semacam tumbuh-tumbuhan, daunnya dimakan dan rasanya asam. Nama Tikala sudah dikenal jauh sebelum datangnya Belanda (1906).

Sebelum Belanda berkuasa, telah terbentuk dua kelompok masyarakat, yaitu kelompok Sang Tondanan Langngan meluputi kampung Kadundung, Maruang, Mariri, Solo' dan kelompok Sang Petayan, meliputi Tallunglipu, Kondongan, Pamanikan, Tikala, Barana yang lazim disebut Tallung Lipu Sitingayo (Huliselan, 1976 : 3). Setelah Belanda menduduki Tana Toraja, kedua wilayah itu disatukan dengan nama Landschap Rantepao, dan diperintah oleh Pong Maramba. Perkembangan selanjutnya, Rantepao dibagi atas dua distrik, yaitu Kesu dan Tikala. Pada tahun 1962, sesuai SK Gubernur Nomor 1100, dibentuk Kecamatan Rantepao, beberapa kamapung digabung menjadi satu desa. Pada tahun 1968, Tikala menjadi Desa gaya baru, dan pada tahun 1981, Tikala menjadi kelurahan.

PendudukTikala tercata 5485 jiwa (1990), ya'ng dapat dirinci menjadi 2742 jiwa laki-laki dan 2638 perempuan. Menurut agama, yaitu 39 Islam $(0,7 \%), 4317$.Protestan $(78,7$ $\%$ ) , 568 Katolik (10,4 \%) dan Alutta (penganut kepercayaan lama) 561 orang $(10,2 \%)$.

Mata pencaharian orang Tikala sebahagian besar bertani di sawah. Dalam buku Basis Data kelurahan tercatat petani pemilik tanah 653 orang, petani penggarap 610 orang, dan buruh tani 827 orang.

Sampai sekarang masih di kenal suatu lembaga yanag dinamai sa roan. Lembaga itu warganya terikat dengan wilayah teritorial yang dipimpin oleh Ambek Tondok. Ambek Tondok berfungsi menyelesaikan permasalahan warganya sebelum sampai ke pemerintahan kelurahan, dan ia juga menentukan pembahagian daging warganya. 


\author{
III. KEHIDUPAN AGAMA \\ DI KELURAHAN TIKALA
}

A. Kegiatan Pendidikan di Sekolah, Keluarga dan Masyarakat.

Pendidikan orang Toraja melalui sekolah pertama kali diperkenalkan oleh Belanda. Zending Antonie van de Loosdrecht pertama kali menginjakkan kakinya di Tana Toraja, Rantepao pada tanggal 10 Nopember 1913, dan pada waktu itu sudah ada dua Volkschool (Sekolah Dasar) di Tana Toraja.. Loosdrecht adalah utusan dari Gerefor meerde zending Bond (GZB). Yaitu Lembaga Pekabaran Injil yahg didirikan pada tang-gal 6 Februari 1901 di Belanda. Loosdrecht segera mendirikan sekolah zending yang jumlahnya melampaui sekolah yang didirikan pemerintah Belanda. Pada'tahun 1914, telah tercatat 11 sekolah, dan salah satu diantaranya didirikan di Kalambe (masuk Kelurahan Tikala), dan sekolah itu yang terbanyak muridnya, yaitu 116 murid. Pada tahun 1917, didirikan di Barana (wilayah Tikala) normal cursus, lanjutan Voolkschool dipimpin oleh pendeta J. Belksma, pengganti Loosdrrecht, setelah terbunuh (Sarira, $1967: 35$ ).

Di Kelurahan telah berdiri enam Sekolah Dasar, satu SMP dan satu SMA. Sesuai dari data Kantor Pendidikan dan Kebudayaan, anakanak yang berusia enam tahun sudah masuk SD. Tidak diperoleh data penduduk yang berusia enam sampai dua belas tahun sebagai usia muris sekolah dasar, yang ada ialah usia lima tahun sampai empat belas tahun yang jumlah 1557 jiwa, sedangkan murid SD sebanyak 1192 jiwa.
Jumlah murid di SMPN Kalamber sebanyak 512 orang, dan kebanyakan warga masyarakat Tikala. Dari data itu, diperoleh keterangan bahwa kesadaran orang tua terhadap pendidikan anaknya sudah dianggap tinggi. Orang Alutta telah memasukkan juga anaknya pada sekolah dasar, dan diperoleh data bahwa murid yang tercatat sebagai penganut agama Alutta sebanyak dua orang. Sebahagian Alutta merasa tidak keberatan kalau anak-anaknya dicatat sebagai penganut Kristen, dan merka juga ikut kebaktian anak-anaknya pada hari Minggu.

Guru agama di tingkat SD dianggap masih kurarig, karena ada dua sekolah yang tidak ada guru agamanya, empat sekolah yang lainnya masing-masing satu guru, kecuali SDN Kalambe dua guru agamanya. Semua guru agama SD adalah Protestan, jadi murid-murid yang beragama Islam dan Katholik tidak rriemperoleh pelajaran agama. Mereka itu sebahagian keluar, dan sebahagian duduk mendengarkan. Dal am ujian agama, dalam memberikan nilai, Kaktolik diberikan pertanyaan yang bersifat umum, karena ajaran Protestan banyak persamaannya dengan Katolik, sedangkan murid Islam dinilai berdasarkan akhlak sehari-hari.

Murid yang belajar Islam hanya di SMPN Kalambe, dan waktunya sekali dalam satu minggu, yaitu pada sore hari, dan digabung karena muridnya sedikit. Di tingkat SMA, murid Katolik mengambil nilai dari pastor, sedangkan Islam terpaksa ikut belajar agama Protestan untuk mendapatkan nilai. 
Orang Toraja tidak mengenal rumah ibadah sebelum datangnya Islam dan Kristen. Tongkonan selain tempat tingga, juga berfungsi sebagai pusat kegiatan keagamaan, yaitu tempat pelaksanaan upacara rambu tuka (upacara gembira) dan rambu solo (upacara kedukaan atau kematian).

Pada hari Minggu, kedengaran lonceng gereja dimanamana, hampir seluruh kegiatan dihentikan, karena masyarakat pergi ma'minggu (kebaktian hari Minggu). Ketika diadakan penelitian ini, masyarakat sementara menggarap sawahnya. Sesuai pengamatan peneliti, masyarakat tidak pergi ke sawah, kecuali pagipagi sekali, dan menjelang pukul delapan pagi, mrexeka kembali ke rumah. Mereka merasa malu bekerja di sawahnya sementara yang lain pergi ke gereja. Bagi orang Islam, karena tidak ada masjid di Tikala, maka mereka ke Rantepao untuk melaksanakan shalat Jum'at.

\section{B. Bentuk-Bentuk dan Isi Dakwah}

Pada mulanya, yang bertanggung jawab mengabarkan atau menyampaikan Injil atau Al-Kitab adalah zending (Protestan) atau misionaris (Katolik) dari barat (Belanda). Untuk melanjutkan tugas zending itu, telah dibentuk suatu lembaga untuk mendidik calon-calon pendeta. Pada tahun 1947 sampai 1949, dibuka sekolah pendeta dengan seorang guru bernama Dr. S. van der Linde. Pada tahun 1962, didirikan Pusat Latihan Kader, kemudian berubah menjadi Lembaga Pembinaan Kristen, dan pada tahun itu juga dibuka PGAA di Tangmento. Pada tahun 1964, dibuka Sekolah Tinggi Theologia (STTH) di
Rantepao, dan Perguruan Tinggi itulah berhasil mengeluarkan pendeta yang memimpin gereja-gereja, terutama gereja Protestan Tana Toraja. Sampai sekarang, pendeta atau pastor yang dahulu kebanyakan dari Barat, sekarang sudah tidak ada lagi di Tana Toraja, karena sudah dianggap orang Toraja sudah mampu mengabarkan Injil kepada domba-domba.

Dakwah (pengabaran Injil) disampaikan dalam ibadat atau kebaktian. Secara garis besar, kebaktian Kristen di Tikala dapat dibagi atas kebaktian keluarga dan kebaktian kelompok. Kebaktian keluarga, yaitu kebaktian rumah tangga dan kebaktian yang sifatnya insidential seperti kebaktian dalam rambu tuka (upacara kegembiraan) dan rambu solo (upacara kematian) biasanya ditetapkan di Gereja, sedangkan kebaktian kelompok ada yang diatur oleh suatu lembaga di bawah Majelis Gereja, seperti kebaktian khusus wanita, diatur oleh Persekutuan Wanita Gereja Toraja ( PGWT), kebaktian pemuda yang diatur oleh Persekutuan Pemuda Gereja Toraja (PPGT), dan kebaktian anak-anak dan remaja, diatur oleh Sekolah Minggu Kebaktian Madya (SMKM). Selain itu, ada juga kebaktian kelompok yang ditetapkan oleh Majelis Gereja, seperti : 1) kebaktian orang dewasa pada hari Minggu, 2) kebaktian sakramen terdiri atas sakramen Kudus dan sakramen Baptisan,dan 3) kebaktian suci, terdiri atas sidi, nikah, dan pengakuan. Dari beberapa bentuk kebaktian yang disebutkan, kebaktian natal adalah yang paling ramai dan meriah. Kebaktian natal selain diadakan di gereja-gereja, juga diadakan di sekolah-sekolah. 
Pendeta sebagai petugas rohaniawan, mendapat gaji dari jemaatnya. Besarnya fasilitas yang diperoleh seorang rohaniawan tergantung dari banyaknya jemaatnya. Untuk pendeta Protestan Gereja Toraja, telah ditetapkan oleh Badan Sinode sesuai dengan golongannya (seperti pendeta di gereja Kalambe mendapat gaji Rp 216.000), dan mengikuti peraturan pemerintah. Sedangkan pendeta Pantekosta pendapatannya sesuai dengan isi kolete setiap minggu, sedangkan pengantar (pemimpin rohaniawan Katolik) separuh hasil pemasukan untuk Paroki di Rantepao, dan separuhnya untuk pengantar dan pembantunya. Sedangkan dari golongan Islam tidak mendapatkan pelayanan agama dari muballiq-muballiq atau dari KUA kecamatan.

Rohaniawan dalam membawakan khutbah di gereja-gereja atau pengabaran Injil di rumah tangga, tidak hanya membicarakan masalah teologi saja, tetapi tema-tema yang ditampilkan disesuaikan dengan situasi dan keadaan, seperti khutbah menyambut hari anak-anak, pengkhutbah banyak berbicara masalah pentingnya pendidikan anak. Mereka juga banyak berbicara masalah kesehatan, termasuk KB, etos kerja dan sebagainya.

C. Lektur Keagamaan yang Dimiliki dan Dipakai Masyarakat

Yayasan Pendidikan Kristen Tana Toraja (Y K K T) adalah suatu lembaga yang mengelola masalah pendidikan di lingkungan Kristen Protestan Tana Toraja. Di Kelurahan Tikala, kecuali S M A Kristen, tidak ada sekolah milik Kristen, sekalipun SMPN Kalambe yang dahulu tempat sekolah zending. Karena semua sekolah itu milik pemerintah, maka lektur keagamaan yang dipakai sesuai dengan yang telah ditetapkan oleh pemerintah dalam hal ini Departemen $\mathrm{P}$ dan $\mathrm{K}$, baik di tingkat $\mathrm{SD}$, maupun di tingkat SMP. Kecuali S M A Kristen, kurikulum yang dipakai adalah kurikulum yang ditetapkan Y PKT, setelah dipadukan dengan kurikulum yang dikeluarkan oleh Departemen $\mathrm{P}$ dan $\mathrm{K}$.

Protestan Tana Toraja dan Katolik menerbitkan buku yang memuat garis-garis besar isi khutbah yang akan dibawakan setiap hari Minggu. Sedangkan Pantekosta isi khutbah diserahkan kepada pendeta atau gembala sidang (anggota Majelis). Untuk Protestan Tana Toraja, buku khutbah itu dinamai Membangun Jemaat, dan ditentukan masa berlakunya, sedangkan buku khutbah Katolik dinamai Ibadat Hari Minggu.

Judul-judul khutbah yang ada dalam buku itu sangat simpel, seperti dalam buku Membangun Jemaat: Siapakah Allah Kita. Hidup dalam Perjanjian, Iman dan Perbuatan, sedangkan judul-judul dalam khutbah Katolik, Ibadat Hari Minggu, seperti : Allah Tritunggal, Masyarakat Kita, Syarat-syarat Mengikuti Yesus, Pahala Mengikuti Yesus. Kedua buku 1 seri khutbah di atas, hanya dimiliki rohaniawan yang membawakan khutbah atau kebaktian di gereja. Kemampuan untuk mengembangkan garis-garis besar isi khutbah itu tergantung pada pendeta atau rohaniawan sampai dimana ia dapat meberi pe- 
nafsiran kemudian dihubungkan dengan masalah yang dihadapi masyarakat dalam kehidupan sehari-hari..

Kelekturan yang dimiliki masyarakat hanya Injil (AUKitab) dan Nyanyian Rohani, itupun terbatas jumlahnya, hanya masyarakat terpelajar, seperti pegawai, mahasiswa atau murid sekolah menengah. Sedangkan masyarakat kebanyakan, mereka tidak membawa buku ke gereja, terutama masyarakat yang tinggal di daerah terpencil. Protestan Toraja memakai buku nyanyian Rohani yaitu Kidung Jemaat, berbahasa Indonesia ditebitkan PGI, selain itu, nyanyian rohani berbahasa daerah yang berjudul Panaman Masallo dan Pa'pudian.

Stasi Katolik memakai buku nyanyian rohani bernama Mada Bakti. Di dalam buku itu tercantum liturgi gereja, sedangkan nyanyian rohani yang berbaha, yang dikutip juga dari Mada Bakti. Kristen Pantekosta selain memiliki kitab Injil, pendetanya jugam emiliki beberapa buku bacaan seperti : buku petunjuk dalam pelayanan jemaat yang berjudul Apa yang kita Percaya dan Mengajar Pejabat Gereja Sebagai Gembala Sidang, Pujian Bagi Allah (nyanyian). Selain buku di atas, pendeta juga memiliki hasil seminar doktrin dari gereja Pantekosta Serikat di Indonesia (GPSDI) Institut Theologi Rema (ITR) Bandung. Sedangkan golongan Islam hanya memiliki Alqur'an, itupun tidak semua rumah tangga terdapat kitab Alqur'an.

D. Kepemimpinan dan Organisasi Keagamaan

Dilihat dari persepsi keagamaan, masyarakat Tikala dapat dibagi atas tiga kelompok, yaitu-1) to salllang (Islam), 2) alukta (penganut kepercayaan lama), dan 3) to sarani (Kristen).

Diperoleh kesulitan untuk menentukan siapa orang Islam yang dianggap sebagai tokoh atau pemimpin Islam di Tikala. Sampai sekarang belum mempunyai wadah yang dapat mempertemukan mereka. Diperoleh informasi bahwa umai Islam di Tikala tidak pernah mengadakan upacara keagamaan seperti Maulid atau Mi'raj. Islam dianggap sebagai orang luar, sekalipun Islam lebih dahulu masuk di Tikala (termasuk Tana Toraja secara keseluruhan) dari Kristen, dalam arti sudah ada orang Islam masuk di Tikala dan befhasil memasukkan Islam penduduk setempat, namun mereka itu bukan pendakwah atau spesialisasi penyebar Islam, tetapi mereka itu pedagang (kebanyakan dari Duri, Enrekang), dan mereka menetap dan kawin mawin dengan penduduk setempat.

Golongan Alukta sebagai sisa-sisa penganut kepercayaan nenek moyang Toraja semakin hari semakin berkurang jumlahnya, dan posisinya semakin sulit. Mereka diakui sebagai pengikut agama Hindu atas prakarsa parandangan ada', yaitu organisasi Alukta yang berpusat di Makale. Pengakuan itu berlangsung sejak tahun 1969 sesuai dengan Surat Keputusan Direktur Jenderal Bimbingan Masyarakat Hindu dan Budha No. Dh/H/200-VI/69 tanggal 15 Nopember 1969, agama baru itu tetap dianggap asing, dan secara organisasi, tidak pernah diadakan semacam pembinaan terhadap warga masyarakat Alukta untuk memberi pemahaman 
mengenai agama Hindu, sehingga mereka tidak mengetahui agama baru itu.

Pemimpin keagamaan Alukta dinamai to minaa. Ia dianggap sebagai orang yang dapat berhubungan dengan Puang Matua (Tuhan Pencipta) dan deata-deata (dewadewa). To minaa memimpin doa dan upacara-upacara seperti siklus hidup pertanian, mulai medatu (menabur benih), marakan (memetik buah pertama), sampai selesai upacara panen. Selain itu, to minaa memimpin upacara marara banua (pentahbisan tongkonan), dan ia dianggap mampu mengobati berbagai penyakit, terutama penyakit yang dapat gangguan bombo (roh orang mati). To minaa biasanya berasal dari golongan bulo diapa (orang kebanyakan). Sebagai to minaa, ia tdiak memperoleh pendapatan tertentu. Ia hanya mendapatkan.pemberian sukarela dari masyarakat. To minaa bekerja seperti masyarakat kebanyakan, seperti bertani, memelihara babi, menyadap enau.

Dalam agama Kristen, setiap aliran mempunyai susunan oranisasi tersendiri. Secara garis besar, Kristen dapat dibagi atas Katolik dan Protestan. Untuk susunan organisasi Katolik berlaku seluruh dunia, dan yang tertinggi adalah Paus Yohannes berkedudukan di Roma, kemudian jabatan uskup selanjutnya paroki. Protestan terbagi atas beberapa aliran. Pantekosta yang terdiri atas beberapa aliran, juga termasuk dari Protestan, dan setiap aliran mempunyai susunan organisasi tersendiri.
Protestan Toraja adalah aliran yang terbesar di Tana Toraja, dan termasuk di Kelurahan Tikala.

\section{KESIMPULAN}

Kelurahan Tikala dihuni oleh mayoritas Kristen Protestan 78,7 \%, Katolik 10,4 \%, Islam 0,7 \%, dmAlutta $10,2 \%$. Pantekosta termasuk bahagian dari Protestan yang terdiri atas Pantekosta Serikat, Gereja Tuhan di Indonesia, dan Pantekosta Betlehem, dan masingmasing mempunyai satu gereja. Protestan Toraja adalah yang terbanyak pengikutnya, dan mempunyai tujuh gereja. Sedangkan Islam dan Alutta tidak mempunyai tempat ibadah khusus.

Orang Kristen mendapat pelayanan keagamaan secara intensif dari pendeta atau rohaniawan. Selain di gereja, mereka juga mendapat pelayanan dalam kebaktian rumah tangga. Lektur keagamaan yang dipakai hanya Injil atau Al-Kitab, itupun terbatas pada orangorang terpelajar. Beberpa anggota jemaah mengeritik pendeta dalam memberikan pelayanan seperti seringnya terlambat rohaniawan dan materi khutbah atau penyampaian dianggap tidak dikaitkan dengan perkembangan yang dihadapi masyarakat.

Orang Islam juga mengkritik Urusan Agama, karena tidak pernah berkunjung untuk memberikan pelayanan keagamaan. Lektur keagamaan yang dimiliki hanya mushaf Alquran, dan itupun tidak semua rumah tangga terdapat Alquran. 
KEHIDUPAN BERAGAMA MASYARAKAT TATOR

STUDIKASUS DI KELURAHAN TIKALA RANTEPAO TANA TORAJA

DAFTAR BACAAN

Badan Pekerja Sinode Gereja Toraja,

Tata Gereja Toraja, Rantepao,

1981.

Fuad Moch, Sy., Islam di Tana Toraja,

Posisi Religius dari Persekutuan

Kultural Masyarakat Muslim

Madandan Tana Toraja, Laporan

Penelitian, PLPIIS UNHAS,

Ujungpandang, 1985.

Huliselan, Mus. J., Keluarga dalam Tongkonan, Studi tentang Perubahan Sosial, Laporarn penelitian PLPIIS UNHAS, Ujungpandang, 1976.

Ihromi, T.O., Sistim Kekerabatan pada Suku Toraja Sadan, Berita Antropologi, Th. VII, No. 21. Mei 1975.

Ismail Arifuddin, Perwujudan Ketakwaan Terhadap Tuhan Yang Maha Esa dalam Sistim Sosial Budaya Masyarakat Tana Toraja, Balai Penelitian Lektur Keagamaan, Ujungpadang, 1989.

Sarira, J. A, B A., Benih Yang Tumbuh, Survey Gereja Toraja, Rantepao, No. 6., Badan Pekerja Sosial Kristen Toraja Rantepao, Ende Flores, 1976

-Sketsa Pendidikan Kristen Gereja Toraja, 1913 - 1976, Panitia Dasa Warsa Pendidikan Kristen Gereja Toraja, Makale, 1976. 